\title{
Combining remote sensing and household level data for regional scale analysis of land cover change in the Brazilian Amazon
}

\author{
Luciana de Souza Soler $\cdot$ Peter H. Verburg
}

Received: 11 February 2009/Accepted: 16 December 2009/Published online: 5 January 2010

(C) The Author(s) 2010. This article is published with open access at Springerlink.com

\begin{abstract}
Land cover change in the Brazilian Amazon depends on the spatial variability of political, socioeconomic and biophysical factors, as well as on the land use history and its actors. A regional scale analysis was made in Rondônia State to identify possible differences in land cover change connected to spatial policies of land occupation, size and year of establishment of properties, accessibility measures and soil fertility. The analysis was made based on remote sensing data and household level data gathered with a questionnaire. Both types of analyses indicate that the highest level of total deforestation is found inside agrarian projects, especially in those established more than 20 years ago. Even though deforestation rates are similar inside and outside official settlements, inside agrarian projects forest depletion can exceed $50 \%$ at the property level within 10-14 years after establishment. The data indicate that both small-scale and medium to largescale farmers contribute to deforestation processes in Rondônia State encouraged by spatial policies of land occupation, which provide better accessibility to forest fringes where soil fertility and forest resources are important determinants of location choice.
\end{abstract}

Keywords Land cover change - Deforestation . Amazon · Brazil $\cdot$ Remote sensing $\cdot$ Household survey · Rondônia State

L. de Souza Soler $(\bowtie) \cdot$ P. H. Verburg

Land Dynamics Group, Wageningen University,

P.O. Box 47, 6700 AA Wageningen, The Netherlands

e-mail: 1soler@wur.nl

P. H. Verburg

Institute for Environmental Studies, VU University Amsterdam,

De Boelelaan 1087, 1081 HV Amsterdam, The Netherlands

\section{Introduction}

Spatial variability associated with the diversity of geopolitical issues, actors, socioeconomic contrasts, public policies and biophysical aspects, and land use history has been addressed in a considerable number of studies to better understand land use/cover change in the Brazilian Amazon (Aguiar et al. 2007; Arima et al. 2005; Becker 2004; Fearnside 2005; Laurance et al. 2002, 2004; Millikan 1992; Moran et al. 2000; Soares-Filho et al. 2006). From these studies, it can be concluded that land cover changes in the Brazilian Amazon can only be understood by an in-depth comprehension of both land use history and the spatial variability of biophysical and socio-economic factors.

Land change trajectories in Rondônia State are strongly connected to spatial policies of land reform. Since the early 1970s, the establishment of official settlements (agrarian projects) has attracted peasants mainly from the southern region of Brazil. These policies also attracted a diversity of actors such as landless migrants, squatters, loggers, miners and ranchers (Becker 1997; Coy 1987; Fearnside 2008; Machado 1989). As a consequence, today the occupation of Rondônia is characterized by official agrarian projects established at distinct periods, spontaneous colonization by medium and big farmers, conservation reserves, indigenous areas and illegal occupation areas.

Land use in Rondônia State can be characterized by a pasture dominance of cattle-raising activities (IBGE 1970, 1996, 2006). Pasture expansion has occurred mainly over forest remnants in the most accessible areas, where older settlements are located (Alves 2002; Cardille and Foley 2003; Machado 1998). Highways and population density play important roles in driving deforestation (Alves et al. 1999; Laurance et al. 2002), while secondary forest occurs at the forest fringes usually in the back of the lots (Alves 
et al. 2003; Soler et al. 2009). The soil (fertility) conditions and spatial heterogeneity of the terrain can influence farmers' decision to deforest their plots (Browder et al. 2004, 2008; Fearnside 1986). In addition, land occupation history plays an important role in the spatial distribution of household types and plot size (Coy 1987; Millikan 1992). Significant differences were found in deforestation between small and big farmers at the Amazonian scale (Fearnside 1993).

According to estimates based on remote sensing data, official agrarian projects created between 1997 and 2002 were responsible for $15 \%$ of the total deforested area in the Brazilian Amazon up to 2004, mainly in Pará, Rondônia and Mato Grosso states (Brandão and Souza 2006). These figures indicate a significant contribution of small farmers to the overall deforestation. At the same time, the aggregation of existing lots into larger farms is also frequently mentioned as a determining factor of deforestation processes (Coy 1987; Escada 2003; Pedlowski et al. 1997). The process of land aggregation is difficult to derive from remote sensing data, and household level surveys are necessary to study such processes. Household level studies can never cover large regions even with an exhaustive sampling. Therefore, the combination of different levels of information such as remote sensing, maps and census data together with household level information can provide a detailed and complementary comprehension of land cover change and its determinants (Lorena and Lambin 2009; Overmars and Verburg 2005). By combining both remote sensing and household level estimates, this study aims to analyze deforestation as a function of the land use planning history and correlate deforestation to possible determinants at regional scale in Rondônia State.

\section{Methods}

\section{Study area}

The study area is located in the south-western part of the Brazilian Amazon (see Fig. 1), including 30 municipalities in the northeast of Rondônia State. The area encompasses

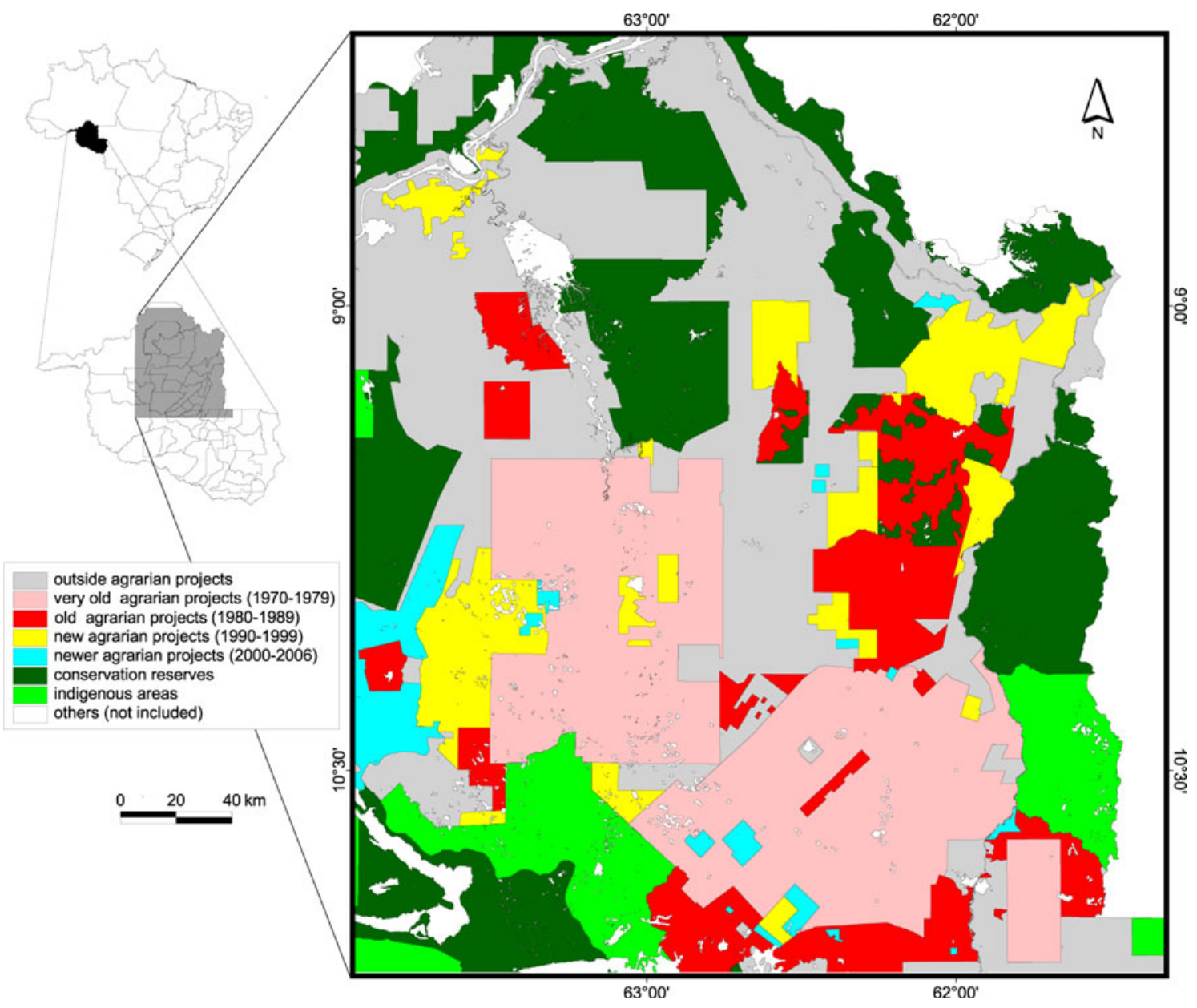

Fig. 1 Location of the study area within Brazil and Rondônia limits indicating the delineation of the agrarian projects according to year of establishment, conservation reserves and indigenous areas 
$86382 \mathrm{~km}^{2}$, which corresponds to $36 \%$ of Rondônia State and $2.2 \%$ of the Brazilian Amazon. The dominant natural vegetation is classified as dense tropical rain forest, but patches of savannah are found in the northern part (RADAMBRASIL 1978). The regional climate is classified as Tropical Rainy, according to the Köppen classification, with a dry season from June to September and a rainy season from October to May (Rondônia 2004). The predominant soils are Ferralsols, Arenosols, Planosols and Gleysols, according to FAO classification (Rondônia 2000). The terrain is mostly flat (slope $0-4 \%$ ), but undulating terrain $(8-20 \%)$ is observed near river valleys and a steeper area (20-38\%) occurs in the southwest.

The area is characterized by old and new frontiers of colonization, which are formed by official agrarian projects and spontaneous settlements occupied by small and medium-sized landholders. In 2008, agrarian projects occupied $38 \%$ of the study area, while spontaneous colonization and unclaimed land represented $31 \%$ of the area. Conservation reserves and indigenous areas covered 21 and $8 \%$, respectively (see Fig. 1). During the last four decades, agrarian projects have been created by the National Institute for Colonization and Agrarian Reform (INCRA) in different areas of the Brazilian Amazon. Initially, these land distribution was an attempt to minimize land conflicts in the Center-south part of Brazil, resulting from a labor force surplus caused by agricultural change (from coffee to soybean and wheat) and mechanization (Browder et al. 2008; Millikan 1992). However, intense migration and population growth were also stimulated by land availability and subsidies until the mid-1980s, adding to a more structured economy, social organization and accessibility by roads in the following years (Becker 2004). In Rondônia State, the total population increased from 70 thousand to 500 thousand inhabitants between 1960 and 1980 (IBGE 1981). In 2006, census estimates indicated more than 800 thousand inhabitants only within the limits of the study area, which represented $60.4 \%$ of Rondônia's total population (IBGE 2007).

The area is crossed by the highway BR-364, which was built in the early 1960s to connect the south-western Amazon to Brasília and is still considered the main connection to the large consumption markets such as São Paulo and Rio de Janeiro. Most of the important cities in the study area are located along the BR-364 such as Porto Velho, Ariquemes, Ji-Paraná, Jarú and Ouro Preto d'Oeste. However, some peripheral towns have increased their economic importance in the last decade including Buritis, Campo Novo de Rondônia, Machadinho d'Oeste and Cujubim (IBGE 2000, 2007). Fieldwork observations, as part of the study presented in this paper, indicate that developments are related to land availability, beef and milk markets and logging, as well as soil fertility mainly in Buritis and Campo Novo de Rondônia.
Pasture has become the dominant land use type not only inside big farms, but also in medium and small lots. Between 1996 and 2006, pasture areas increased 24\% in Rondônia State mainly at the expense of forested areas (IBGE 1996, 2006). In general, small farmers apply poor land management in terms of manure management, mechanization or fertilizer application. Although medium/ big farmers are better capitalized, only a small number of them apply proper land management. In spite of the lack of investments on land management, Rondônia's importance on national milk markets increased significantly in the last years, being ranked today as the seventh most important state in dairy production in Brazil (IBGE 2008). Sanitary barriers for beef and milk production have improved the overall quality as a result of law enforcement and market requirements. This land use trajectory is also related to the household life cycle of medium and small landholders, who consider cattle raising as a long-term source of income that requires moderate labor.

\section{Database and data preparation}

In order to make an analysis of land cover change in Rondônia, three different types of data were required, namely, spatial data, statistical data and household level data. Two types of analyses were applied: a spatial analysis and a household level analysis. Table 1 provides an overview of the data used in the two different analyses, their sources and units of measurement. In the following sections, the data and their processing are described in more detail.

\section{Spatial data}

The spatial data included a multi-temporal database of land cover maps for 2000 and 2008 based on remote sensing images (INPE 2009). These land cover maps are the official instrument to monitor deforestation in the Brazilian Amazon, and for that reason, they have been the main data source of deforestation estimates for the scientific community. The land cover maps are based on a spectral linear mixture model followed by a supervised classification procedure of Landsat/TM images and final editing by visual interpretation. These land cover maps are used to derive yearly land cover maps at a spatial resolution of $60 \mathrm{~m}$ classified into three classes-forest, non-forest and deforestation. Validation of the final land cover maps is done by expert knowledge through visual interpretation with the support of historical series of fieldwork observations. The overall error is estimated at 4\% (INPE 2009).

Further spatial data consisted of geographical limits of conservation reserves and indigenous areas (IBAMA 2005), geographic limits and year of establishment for all 
Table 1 Data description, data sources and spatial units subdivided by the different types of analysis employed

\begin{tabular}{|c|c|c|c|}
\hline Variable & Description & Source & Spatial unit \\
\hline \multicolumn{4}{|l|}{ Spatial analysis } \\
\hline $\begin{array}{l}\text { Percentage deforested in } 2000 \\
\text { and } 2008\end{array}$ & $\begin{array}{l}\text { Percentage deforested per cell derived from } \\
\text { land cover maps based on Landsat/TM } \\
\text { images classified for } 2000 \text { and } 2008\end{array}$ & INPE (2009) & Pixels $(60 \mathrm{~m} \times 60 \mathrm{~m})$ \\
\hline $\begin{array}{l}\text { Size of forest clearing in } 2000 \\
\text { and } 2008\end{array}$ & $\begin{array}{l}\text { Calculated size of continuous forest clearing } \\
\text { from land cover maps (classes (ha): }<6.25 \text {, } \\
6.25-10,10-20,20-40,40-60,60-100 \\
100-200,>200)\end{array}$ & INPE (2009) & Pixels $(60 \mathrm{~m} \times 60 \mathrm{~m})$ \\
\hline \multirow[t]{3}{*}{ Zoning areas } & Municipalities' boundaries & IBGE (2000) & Scale 1: 250000 \\
\hline & $\begin{array}{l}\text { Geographical limits of official agrarian } \\
\text { projects per year of establishment (very old } \\
\text { 1970-1979, old 1980-1989, new 1990- } \\
\text { 1999, newer 2000-2008) }\end{array}$ & INCRA (2008) & Scale 1: 100000 \\
\hline & Conservation reserves and indigenous areas & IBAMA (2005) & Scale 1: 250000 \\
\hline $\begin{array}{l}\text { Accessibility (cost distance to } \\
\text { roads) }\end{array}$ & $\begin{array}{l}\text { Travel time to the nearest road by different } \\
\text { means of access (as described in Table 2) }\end{array}$ & $\begin{array}{l}\text { ANTT, ANTAQ, } \\
\text { Fieldwork information }\end{array}$ & Pixels $(250 \mathrm{~m} \times 250 \mathrm{~m})$ \\
\hline Density of roads & $\begin{array}{l}\text { Number of cells with roads/total number of } \\
\text { cells in different zoning areas }\end{array}$ & $\begin{array}{l}\text { Rondônia (2000), } \\
\text { Landsat/TM images }\end{array}$ & Pixels $(250 \mathrm{~m} \times 250 \mathrm{~m})$ \\
\hline Road patterns & $\begin{array}{l}\text { Classification of generalized road patterns } \\
\text { (orthogonal, dendritic or irregular) }\end{array}$ & $\begin{array}{l}\text { Rondônia (2000), } \\
\text { Landsat/TM images }\end{array}$ & Pixels $(250 \mathrm{~m} \times 250 \mathrm{~m})$ \\
\hline Property size & $\begin{array}{l}\text { Percentage of area allocated to property per } \\
\text { size (classes: }<60,60-240,>240 \text { ha) per } \\
\text { municipality in Rondônia in } 2005\end{array}$ & $\begin{array}{l}\text { Census data from } \\
\text { INCRA (2007) }\end{array}$ & Municipality level \\
\hline \multicolumn{4}{|l|}{ Household level analysis } \\
\hline $\begin{array}{l}\text { Percentage deforested per } \\
\text { property in } 2000 \text { and } 2008\end{array}$ & $\begin{array}{l}\text { Percentage deforested per property in } 2000 \\
\text { and } 2008 \text {, reported by landholders. }\end{array}$ & \multirow{6}{*}{$\begin{array}{l}\text { Household level survey } \\
\text { conducted with } 86 \\
\text { landholders in June } \\
2008 \text { either inside or } \\
\text { outside agrarian } \\
\text { projects established } \\
\text { within } 1970-2008 \text { in } \\
\text { the study area }\end{array}$} & Property level \\
\hline $\begin{array}{l}\text { Average size of forest clearing } \\
\text { within } 2000 \text { and } 2008\end{array}$ & $\begin{array}{l}\text { Estimated size of forest clearing from area } \\
\text { deforested inside the lots reported by } \\
\text { landholders }\end{array}$ & & \\
\hline Year of establishment & Year of official establishment in the lot & & \\
\hline Property size & Size of properties in 2000 and 2008 & & \\
\hline Accessibility & $\begin{array}{l}\text { Distance to the main road (BR-364) and } \\
\text { means of access to the property (paved, } \\
\text { unpaved road) }\end{array}$ & & \\
\hline Soil fertility & $\begin{array}{l}\text { Fertility level reported by landholders } \\
\text { (classes: high, medium, low) }\end{array}$ & & \\
\hline
\end{tabular}

agrarian projects in the study area (INCRA 2008) and the road and river networks (Rondônia 2000). The remote sensing images were also used to improve the map of the road network.

In addition to these spatial data, statistical data were used to indicate the size of the properties per municipality in Rondônia in 2005. Property size is reported in three classes: smaller than 60 ha, between 60 and 240 ha and larger than 240 ha (INCRA 2007). Although these data are based on a sample of individual properties, they are only available aggregated at the level of municipalities.

\section{Household level data}

Throughout the study area, a total of 86 interviews were conducted with landholders during June 2008 in order to record land use histories in official agrarian projects with different years of establishment. The survey resulted in 19, 17, 29 and 16 interviews in agrarian projects established in the 1970s, 1980s, 1990s and after 2000, respectively. In areas of spontaneous colonization, i.e., outside the agrarian projects, two interviews were conducted with big farmers and three in invaded areas.

The questionnaire adopted in the household level survey was based on a template proposed by CIFOR (Sunderlin and Pokam 2002) and adapted by Lorena (2008). The final questionnaire was condensed to focus on land use history and specific characteristics of land use systems. Thus, besides information to reconstruct the land use/cover history from 2000 to 2008, the questionnaire also included questions related to soil fertility, year of occupation, rate of deforestation and accessibility. In invaded areas, this 
questionnaire was adapted as there is no information about the total plot size; instead the occupied area was recorded. Big farmers could not be interviewed with the preformatted questionnaire; instead they were asked about their production systems, the areas allocated for different land use types and their rates of change.

\section{Analysis of spatial data}

Two different analyses were made based on the land cover maps for 2000 and 2008. The first analysis aimed at relating the deforestation processes to the land use planning history. The second analysis focused on other determinants of the deforestation patterns.

For the analysis of the influence of land use planning, deforestation was compared according to the land use planning history and zoning. Deforestation inside and outside agrarian projects of different years of establishment, conservation reserves and indigenous areas were compared. The year of establishment is expected to explain differences in the rate of deforestation between old and new frontiers (Dale et al. 1994; Fearnside 1986). For each of these zones, the percentage deforested and the percentage deforested per size of forest clearing were calculated for 2000 and 2008. Forest clearings were subdivided into eight categories: smaller or equal to $6.25,6.25-10,10-20$, 20-40, 40-60, 60-100, 100-200 ha and larger than 200 ha. In all analysis, pixels of urban areas, rock outcrops, savannah areas, rivers and other water bodies were excluded.

The location of deforestation was related to a series of potential determinants of deforestation. Potential determinants analyzed besides the zoning, year of establishment and the size of the forest clearings were the size of the properties, road patterns and the overall accessibility. Previous studies concluded that accessibility by roads and rivers network is an important driver of deforestation (Aguiar et al. 2007; Alves et al. 2003; Soler et al. 2009). However, it is hypothesized that its influence on deforestation should decrease after some years of colonization (Fujisaka et al. 1996). In addition, the size of deforested areas and property size are indicators of differences in deforestation processes and types of farming (Alves 2002; Escada 2003; Fearnside 1993).

The road pattern typology was defined using simple concepts of geometry as orthogonality, connectedness and sinuosity. Three main patterns were considered in the analysis: regular (or orthogonal), dendritic and irregular. The regular pattern consists of secondary roads perpendicular (or oblique) to the main roads and parallel to each other at a regular distance. The dendritic pattern consists of main roads with several ramifications, where main and secondary roads follow landscape characteristics of slope and drainage network. At last, the irregular road pattern does not follow a preferred direction and is characterized by a tortuous road network.

The roles of accessibility and road density as determinants of deforestation patterns in Rondônia were assessed by relating deforestation to the measures of accessibility and road density, respectively. Density of roads was obtained by dividing the cells with roads by the total number of cells in each zone analyzed. Overall accessibility (travel time to roads) was calculated using cost distance algorithms considering highways, main and secondary roads (paved or not), river network, bays, dams, lakes and lagoons (Verburg et al. 2004). The average travel speed (Table 2) was estimated using fieldwork information and logistic information from Brazilian National Agencies of Terrestrial and Aquatic Transports (ANTT and ANTAQ).

Analysis of household level data

Similar to the spatial data, the household level data were analyzed by comparing the data for different zones, i.e., comparing the agrarian projects per year of establishment. This parallel analysis allowed the comparison of outcomes based on the spatial and the household level data. The analysis focused on information concerning the amount of deforestation at the plots between 2000 and 2008 reported by householders, as well as possible determinants of deforestation. Similar to the spatial analysis, the percentage deforested and the size of forest clearing were determined for the different land use planning zones. The size of forest clearings was estimated using the average area cleared reported by householders within the years considered.

In the second step of the analysis of household level data, four possible determinants of deforestation were evaluated: year of establishment, property size, soil fertility

Table 2 Estimated average travel speed by infrastructure type in Rondônia

\begin{tabular}{lc}
\hline Access type & $\begin{array}{l}\text { Average } \\
\text { speed }(\mathrm{km} / \mathrm{h})\end{array}$ \\
\hline Paved highway & 110.0 \\
Paved main roads & 90.0 \\
Unpaved main roads & 70.0 \\
Secondary roads & 40.0 \\
Paths & 15.0 \\
Main rivers & 23.0 \\
Secondary rivers & 11.5 \\
Tertiary rivers, bays, lagoons, lakes and dams & 5.0 \\
Intermittent rivers, lagoons and flooded areas & 3.0 \\
Deforested areas & 2.0 \\
Secondary forest/forested areas & 0.5 \\
\hline
\end{tabular}


and accessibility. Soil fertility was considered at this level of the analysis and not in the spatial analysis due to lack of data at the appropriate scale for the whole region. Soil fertility is expected to be one of the factors in the decision making, explaining the choice to deforest (Roberts et al. 2002). In addition, we also compared the differences on deforestation rates between aggregated and non-aggregated lots, an analysis only possible with the household level data. Then, ANOVA was used to evaluate accessibility influence on the reported deforestation rates per property between 2000 and 2008. At last, regression analyses of percentage deforested per property against year of occupation, soil fertility, property size and accessibility were done.

\section{Results}

Analysis of spatial data

\section{Deforestation processes and land use planning}

The analysis according to the zoning of the study area shows that deforestation is highly concentrated inside the agrarian projects. Figure 2a illustrates the percentage of forest coverage in the study area for 2008 , while Fig. $2 \mathrm{~b}$ illustrates the percentage deforested in the study area between 2000 and 2008. It can be observed that most of the deforestation within the period of study occurred in new and newer agrarian projects (created in the 1990s and after 2000 , respectively), but also a significant percentage is observed in some old agrarian projects as well as outside the projects. The percentage deforested inside the agrarian projects increased from $62 \%$ of the area in 2000 to $78 \%$ in 2008 (see Fig. 3a). Even though outside the agrarian projects, a much lower percentage of land is deforested, $27 \%$ in 2000, an increase of $13 \%$ was observed between 2000 and 2008. A small percentage of deforested area was observed in 2000 inside the conservation reserves with an increase of 5\% between 2000 and 2008. In the same period, a minor increase of deforested areas $(1 \%)$ was observed inside indigenous areas. These results clearly show that most deforestation is found inside the agrarian projects. However, at the same time, it is clear that deforestation outside the agrarian projects is very large as well and certainly cannot be ignored.

When accounting for the year of establishment of agrarian projects, the analysis showed that deforested areas are highly concentrated inside very old and old agrarian projects, i.e., created in the 1970s and 1980s, respectively (Fig. 3b). These results indicate that the year of colonization is a key determinant in explaining deforestation levels. Although very old and old projects show large deforested areas in 2000, their rates of change between 2000 and 2008 were not as high as in the new and newer projects.

Even though presenting a smaller total area deforested, new and newer agrarian projects faced deforestation between 2000 and 2008 of 28 and $26 \%$ of their total area, respectively. This indicates intense land cover conversions inside recently colonized areas, where the increase of pasture occurs on the expense of forest, secondary forest and small scale agriculture (Alves et al. 2003; Batistella 2001; Cardille and Foley 2003). Such land cover changes are mostly driven by better profits at milk and beef markets, encouraging large to small landholders to increase cattle raising production (Faminow 1997; Fearnside 1997; Walker et al. 2000). In 2008, the average difference in total deforestation between projects established in different years is much smaller: both recent and older projects have high fractions deforested.

The larger part of the deforestation between 2000 and 2008 is due to clearings between 10 and $40 \mathrm{ha}$. Moreover, clearings larger than 100 ha represent a considerable share of the total deforestation in the period (see Fig. 4a). Although the overall area deforested outside the agrarian projects is smaller, forest clearings larger than 40 ha represented $56 \%$ of the deforested area outside agrarian projects in the same period. Even though the amount of deforestation inside conservation reserves and indigenous areas is small between 2000 and 2008, forest clearings larger than 60 ha represented, respectively 40 and $31 \%$ of their deforested areas. The results of this analysis indicate that forest clearings are generally smaller within the agrarian projects areas than outside.

When considering the size of forest clearings in agrarian projects per year of establishment, very similar tendencies for the three oldest groups can be observed (Fig. 4b). For these groups, deforested areas are mostly between 10 and 40 ha. For the older group of agrarian projects, a higher frequency of deforested patches smaller than 10 ha when compared to newer projects is observed, which indicates a higher forest depletion and/or fragmentation. In contrast, in newer agrarian projects deforested patches between 60 and 200 ha and larger than 200 ha represented, respectively, 31 and $17 \%$ of the total deforested areas. An important aspect is that forest clearings smaller than 10 ha are less frequent inside newer projects than in the older ones. Outside the agrarian projects deforested patches larger than 60 ha represent more than $44 \%$ of the deforestation for the mentioned period.

\section{Determinants of deforestation patterns}

Property size In the last years, the process of land concentration has been investigated in the Brazilian Amazon with indications that the size of forest clearing is linked to 
Fig. 2 a Percentage of forest coverage in 2008. b Percentage of area deforested between 2000 and 2008 in the study area
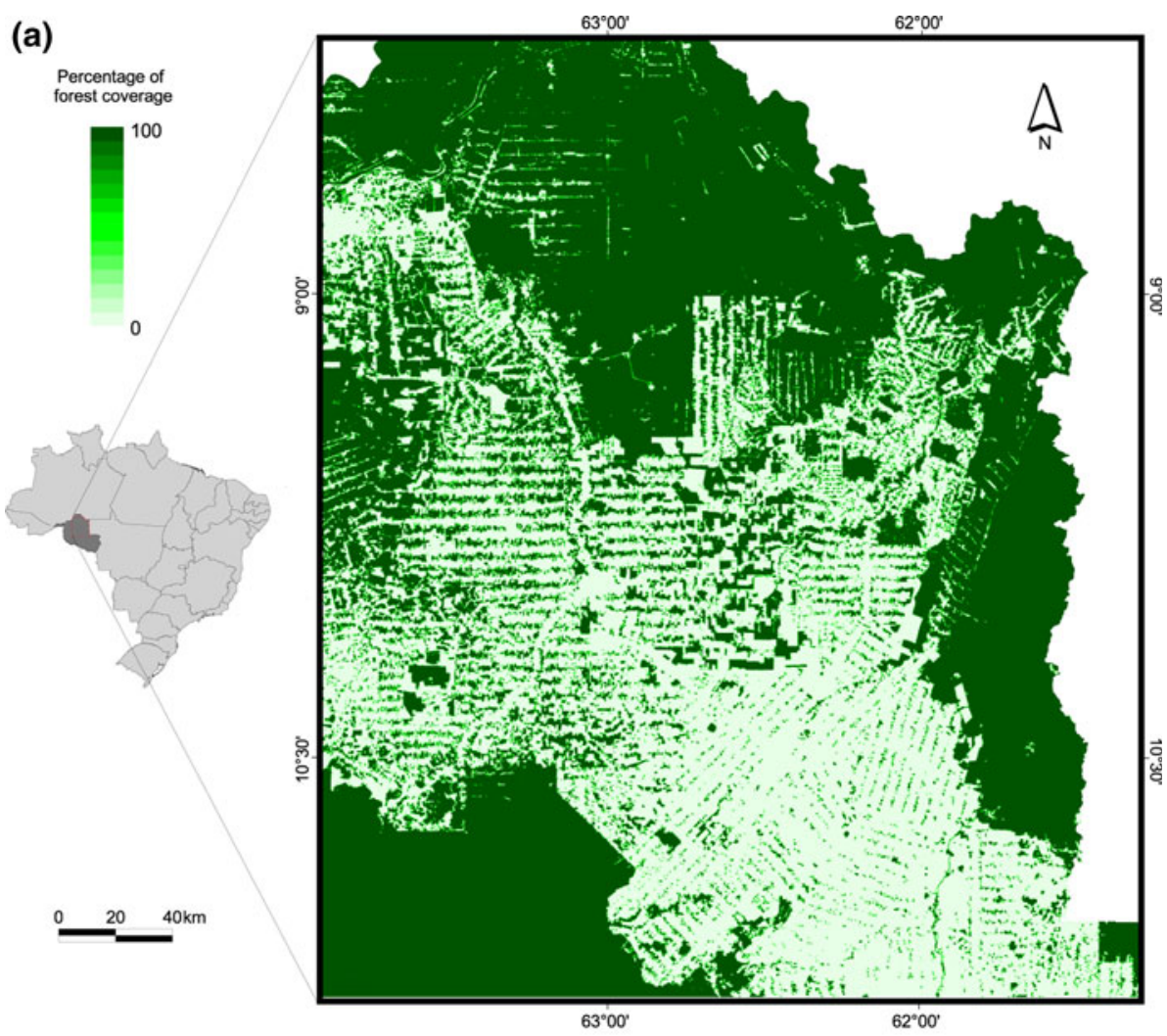

(b)

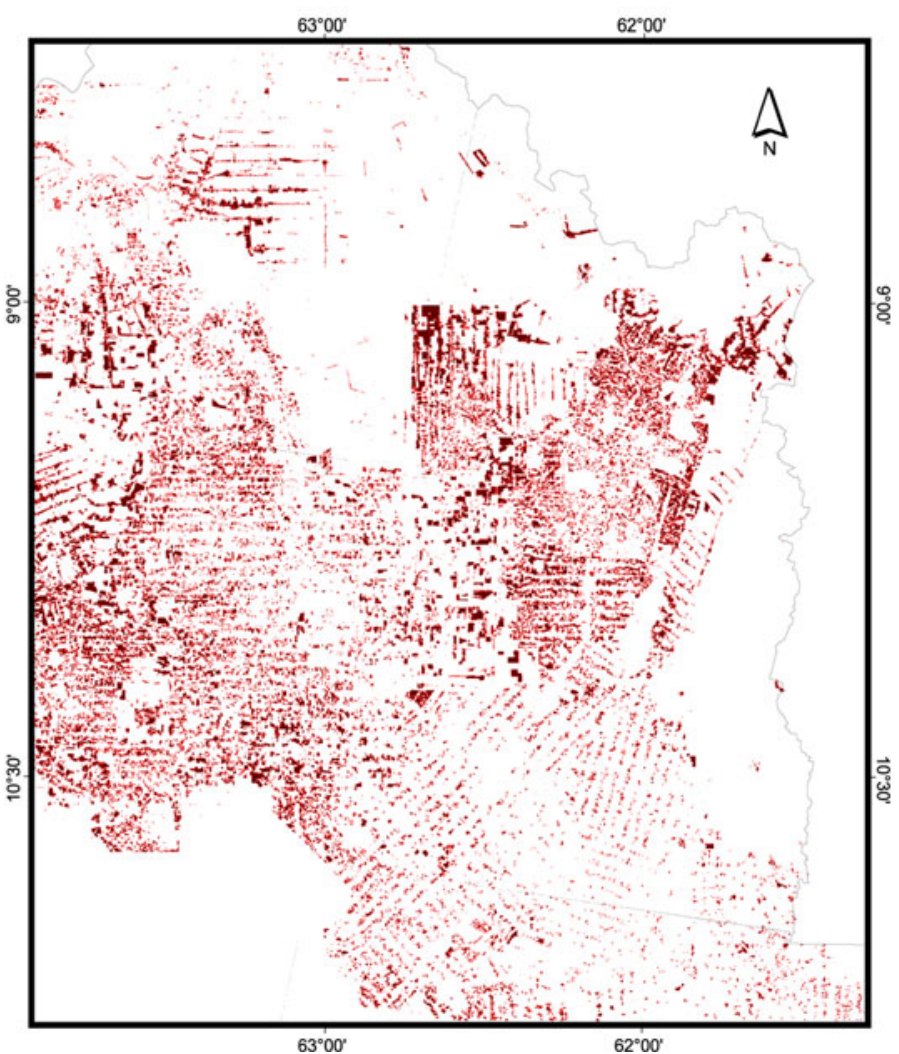

aggregated at the municipality level, which can reveal the correlation between property size and the deforested area in 2008. Simple correlations between the area deforested in the property size (Alves 2002; Fearnside 1993; Mello and Alves 2005). No data of property size are available at the property level. However, census data provide information 
Fig. 3 a Percentage deforested in 2000 and 2008 inside/outside the agrarian projects, conservation reserves and indigenous areas. b Percentage deforested in 2000 and 2008 inside/outside the agrarian project per year of establishment (very old 19701979, old 1980-1989, new 1990-1999, newer 2000-2008), in conservation reserves and indigenous areas
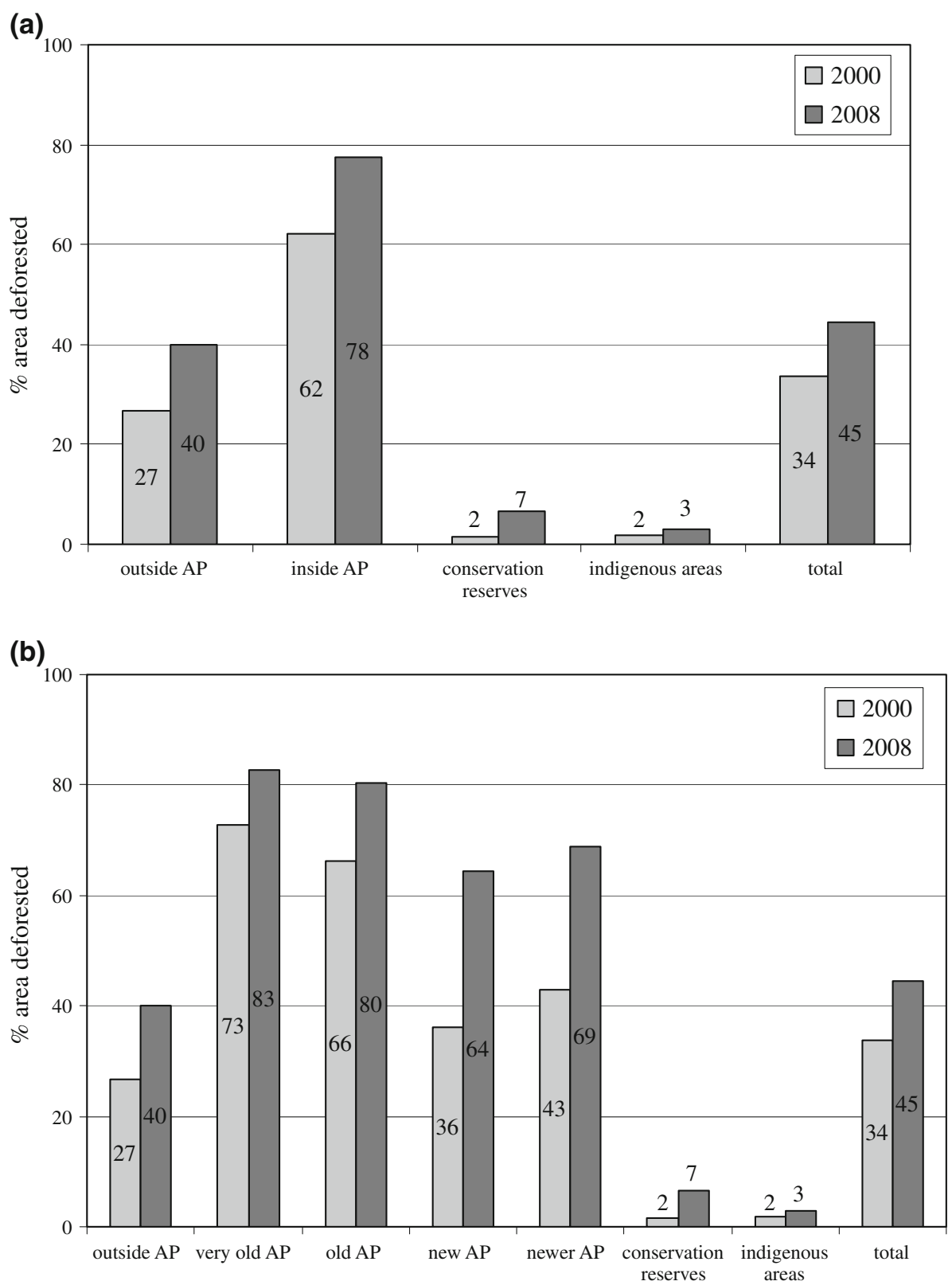

2008 and the percentages of properties (in three classes according to size) showed a strong negative correlation $-0.54(p<0.01)$ between the area deforested and the percentage of area allocated to properties larger than 240 ha. Positive correlations were found for properties smaller than 60 ha as well as for properties between 60 and $240 \mathrm{ha}$, corresponding to $0.41(p<0.05)$ and 0.48 $(p<0.01)$, respectively. These results mainly indicate that deforestation is higher in municipalities with agrarian projects as they enclose predominantly small properties. The correlation between percentage deforested between 2000 and 2008 and the property size distribution is, however, not significant. These results indicate that although small landholders are connected to a large portion of deforestation, larger properties were, for the period of analysis, important contributors to deforestation in the area.

It should be noted that these results are based on aggregated data at municipality level while large variations at the property level may occur. Analysis at the aggregated level may be biased due to scaling problems ('ecological fallacy'). Therefore, these results should be compared to the analysis at household level.

The influence of roads on deforestation It is well known that deforestation patterns are connected to road access, especially in areas of agrarian projects (Alves 2002; Alves et al. 1999; Brandão et al. 2007; Soares-Filho et al. 2001). In order to evaluate the influence of roads on deforestation, 
(a)

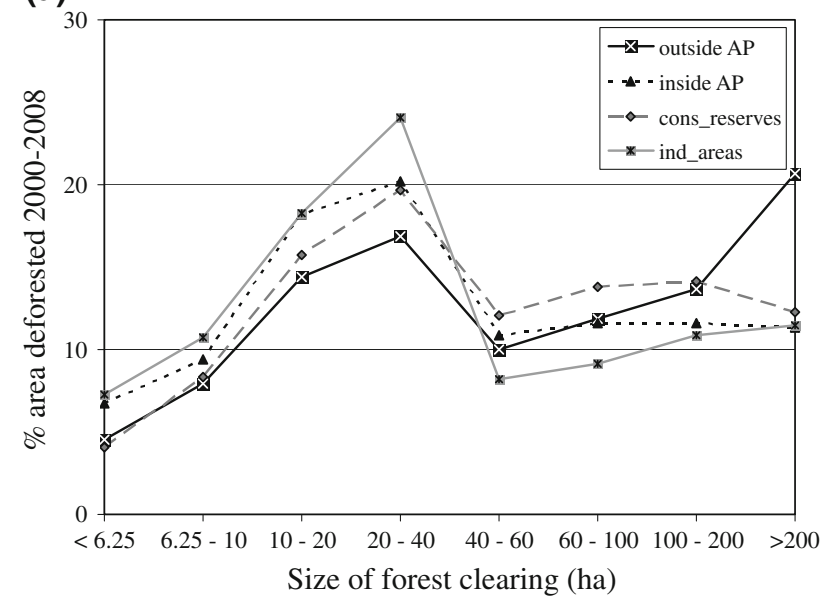

(b)

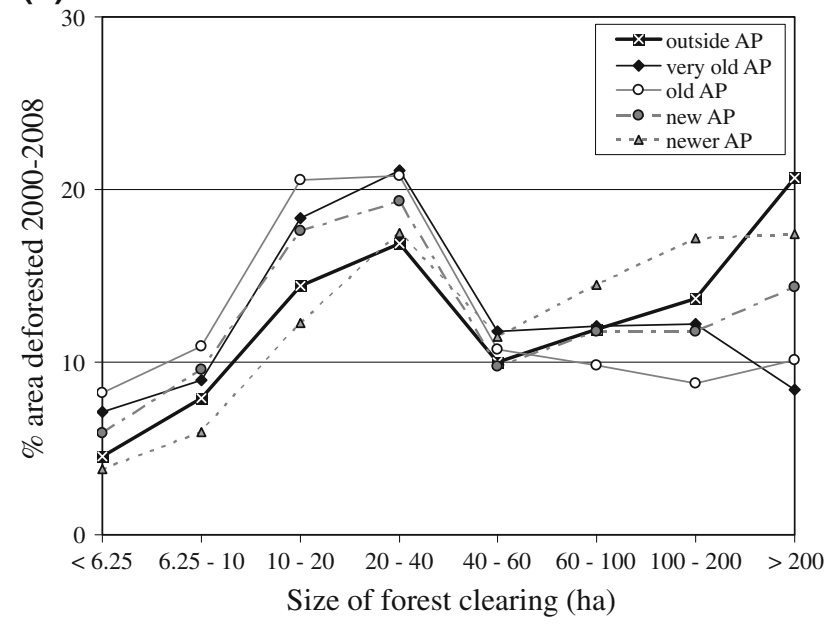

Fig. 4 a Percentage deforested between 2000 and 2008 per size of forest clearing inside and outside the agrarian projects, inside conservation reserves and indigenous areas. b Percentage deforested between 2000 and 2008 per size of forest clearing outside and inside the agrarian projects per year of establishment (very old 1970-1979, old 1980-1989, new 1990-1999, and newer 2000-2008)

the density of roads and the travel time to the nearest road were compared to patterns of deforestation outside and inside the agrarian projects (Table 3). This analysis showed that the accessibility to forest increased more than $76 \%$ in spontaneous colonization, conservation reserves and indigenous areas between 2000 and 2008. Likewise, the travel time to roads in deforested areas of recent and spontaneous colonization was reduced by $64 \%$ in the period of analysis, equalizing to values inside older projects. Forested areas inside agrarian projects showed significantly smaller distances to roads when compared to spontaneous occupation areas.

The density of roads inside deforested areas is much higher than in forested areas. Upon further deforestation, this density decreases as a result of further forest depletion within the existing plots. The density of roads in forested areas did not show a significant change between 2000 and 2008 inside agrarian projects.

Besides the influence of roads on deforestation, an analysis of road patterns may provide an indication of the actors of land use changes. Whereas the regular road pattern is closely related to the well-known fishbone pattern of deforestation, the dendritic road pattern is a result of a new assessment of INCRA's projects to guarantee individual access to water while keeping forest reserves in the surroundings. The irregular pattern is normally related to spontaneous colonization. The regular and irregular road patterns can also be related to selective or indiscriminate logging, respectively (Brandão and Souza 2005). An analysis of road patterns showed that outside the agrarian projects orthogonal and irregular road patterns represent, respectively, 60 and $36 \%$ of the occupation (Table 4). Although dominated by orthogonal road patterns, in the new and newer agrarian projects, respectively, 17 and $26 \%$ of all roads were showing an irregular pattern. In very old projects, orthogonal road patterns are largely dominant (99\%), while in old projects, this percentage is $61 \%$ and the dendritic patterns represent $30 \%$. However, the deforested area did not clearly differ between orthogonal road patterns ( $88 \%$ of the area deforested) and dendritic road patterns ( $86 \%$ deforested). Taking into account the new settlements, 87 and $86 \%$ of the road cells presenting, respectively, orthogonal and dendritic patterns were deforested in 2008, while considering only old settlements, these percentages increased to 96 and $92 \%$, respectively.

Analysis of household level data

Deforestation processes and land use planning

According to the household level data, individual plots are most deforested inside the very old and old agrarian projects (Fig. 5). However, deforestation between 2000 and 2008 was 4 and $36 \%$ of the area in very old and old projects, respectively. The estimates for old projects can be biased because of the absence of a representative number of samples containing the aggregation of lots. Although many big farms with large pasture areas were observed in both very old and old projects, no interviews could be done. This is because big landholders usually live in cities nearby hiring farm hands who are not able to provide detailed information (Walker et al. 2000). Nevertheless, the household level data show that properties sampled in very old and old agrarian projects have, respectively, 18 and $14 \%$ forest remaining while in new and newer projects, respectively, 34 and $46 \%$ are remaining.

The estimates of the percentage deforested for new and newer agrarian projects show a smaller fraction deforested 
Table 3 Mean cost distance to roads and density of roads in 2000 and 2008 in areas inside and outside agrarian projects (AP), conservation reserves and indigenous areas

\begin{tabular}{|c|c|c|c|c|c|c|c|c|c|c|c|c|c|c|}
\hline \multirow{3}{*}{$\begin{array}{l}\text { Variables } \\
\text { Zone }\end{array}$} & \multicolumn{2}{|c|}{$\begin{array}{l}\text { Percentage } \\
\text { deforested }\end{array}$} & \multicolumn{6}{|c|}{$\begin{array}{l}\text { Mean cost distance to roads (min) } \\
\text { (travel time to nearest road) }\end{array}$} & \multicolumn{6}{|c|}{$\begin{array}{l}\text { Density of roads (fraction of pixels } \\
\text { with road segments) }\end{array}$} \\
\hline & \multirow[t]{2}{*}{2000} & \multirow[t]{2}{*}{2008} & \multicolumn{2}{|c|}{ Deforested cells } & \multicolumn{2}{|c|}{ Forested cells } & \multicolumn{2}{|c|}{ All cells } & \multicolumn{2}{|c|}{ Deforested cells } & \multicolumn{2}{|c|}{ Forested cells } & \multicolumn{2}{|c|}{ All cells } \\
\hline & & & 2000 & 2008 & 2000 & 2008 & 2000 & 2008 & 2000 & 2008 & 2000 & 2008 & 2000 & 2008 \\
\hline Outside AP & 27 & 40 & 74 & 26 & 573 & 121 & 384 & 83 & 0.14 & 0.13 & 0.02 & 0.02 & 0.05 & 0.06 \\
\hline Very old AP & 73 & 83 & 29 & 22 & 81 & 47 & 38 & 26 & 0.13 & 0.12 & 0.03 & 0.03 & 0.10 & 0.10 \\
\hline Old AP & 66 & 80 & 23 & 18 & 63 & 38 & 31 & 22 & 0.19 & 0.17 & 0.04 & 0.04 & 0.14 & 0.14 \\
\hline New AP & 36 & 64 & 53 & 20 & 126 & 43 & 82 & 29 & 0.21 & 0.17 & 0.05 & 0.04 & 0.11 & 0.12 \\
\hline Newer AP & 43 & 69 & 63 & 23 & 146 & 51 & 86 & 31 & 0.14 & 0.12 & 0.03 & 0.03 & 0.08 & 0.09 \\
\hline Conservation reserves & 2 & 7 & 248 & 39 & 1,063 & 187 & 1,009 & 177 & 0.15 & 0.14 & 0.01 & 0.01 & 0.01 & 0.02 \\
\hline Indigenous areas & 2 & 3 & 163 & 47 & 1,023 & 228 & 992 & 222 & 0.08 & 0.06 & 0.00 & 0.00 & 0.00 & 0.00 \\
\hline All zones & 34 & 45 & 93 & 28 & 439 & 102 & 375 & 84 & 0.15 & 0.14 & 0.02 & 0.02 & 0.06 & 0.07 \\
\hline
\end{tabular}

Table 4 Percentage of area classified with a typical road pattern outside and inside the agrarian projects, conservation reserves and indigenous areas

\begin{tabular}{lccrcrrrr}
\hline Road pattern & Outside AP & Very old AP & Old AP & New AP & Newer AP & $\begin{array}{l}\text { Conservation } \\
\text { reserves }\end{array}$ & $\begin{array}{l}\text { Indigenous } \\
\text { areas }\end{array}$ \\
\hline Orthogonal & 60.76 & 99.11 & 61.98 & 62.41 & 73.37 & 83.31 & 95.10 \\
Irregular & 36.68 & 0.89 & 7.82 & 17.88 & 26.63 & 12.41 & 4.90 \\
Dendritic & 2.56 & 0.00 & 30.20 & 19.71 & 0.00 & 4.28 & 0.00 \\
\hline
\end{tabular}

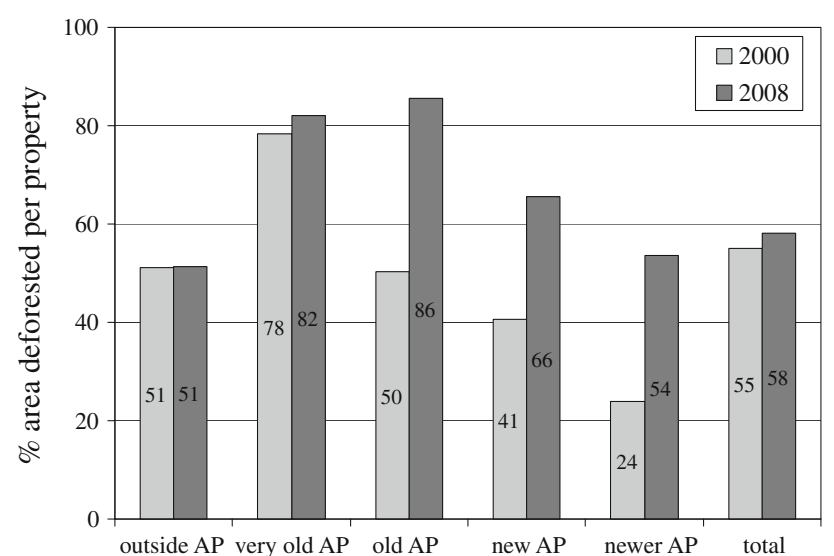

Fig. 5 Percentage deforested per property in 2000 and 2008 inside/ outside the agrarian projects per year of establishment (very old 1970-1979, old 1980-1989, new 1990-1999, newer 2000-2008) based on household level data

for the years 2000 and 2008 when compared to older projects. However, deforestation during the aforementioned period was on average 25 and $30 \%$ of the plot area respectively, indicating a much higher deforestation rate than in the very old agrarian projects.

The analysis of the influence of the size of forest clearings indicates that within very old agrarian projects, the average size of forest clearing was around 0-2 ha/year, while in old agrarian projects, the average size of forest clearing ranged within 1-4 ha/year over the period considered. In new agrarian projects, most properties had an average size of forest clearing of 1-3 ha/year and only a few properties presented values higher than 4 ha/year. Finally, in newer projects, about half of the properties presented an average size of forest clearing around $0-3$ ha/year, while size of forest clearing for the other half was $4-5$ ha/year.

\section{Determinants of deforestation patterns}

In order to investigate the impact of land concentration processes on deforestation at the household level, deforestation rates between aggregated and non-aggregated lots were compared.

The results show that properties with aggregation of lots in new and old agrarian projects faced much higher deforestation rates than non-aggregated lots. However, in areas of newer and very old projects, deforestation rates are similar for aggregated and non-aggregated lots. Figure 6 shows a negative association between the year of occupation and the percentage deforested. This association is less clear in 2008 when compared to the situation in 2000 as a result of intense forest depletion in older properties. At the same time, the relation is biased by some properties in new 


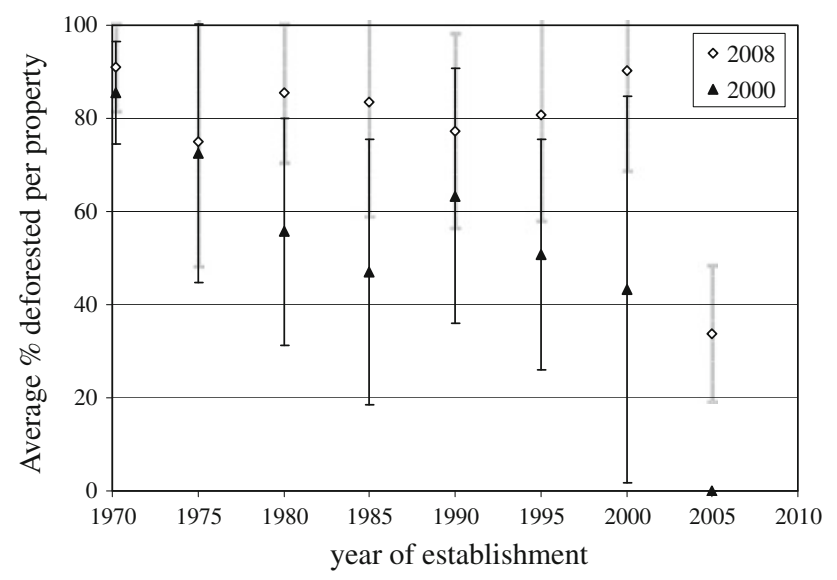

Fig. 6 Relation between year of occupation and percentage deforested per property based on household level data for 2000 and 2008

and newer projects that were established in previously occupied land. Such properties already show forest depletion in the first years of occupation due to land clearing before official establishment of the agrarian project.

For the evaluation of possible relations between fertility and deforestation, three main classes of soil fertility were distinguished in the household level data: low, regular and high. The reported soil fertility was correlated to the percentage deforested per property and the results indicate high fertile areas to be strongly correlated to the percentage deforested for both years. In order to better comprehend such relationships, an ANOVA analysis was performed and the results are illustrated in Fig. 7.

The ANOVA results indicate that the mean percentage deforested is different between the classes of low and high soil fertility in 2008, as well as between regular and high for 2000. For both years, the percentage deforested in low and regular fertile areas was not significantly different, but both means differ from high fertility areas $(p<0.05)$. The

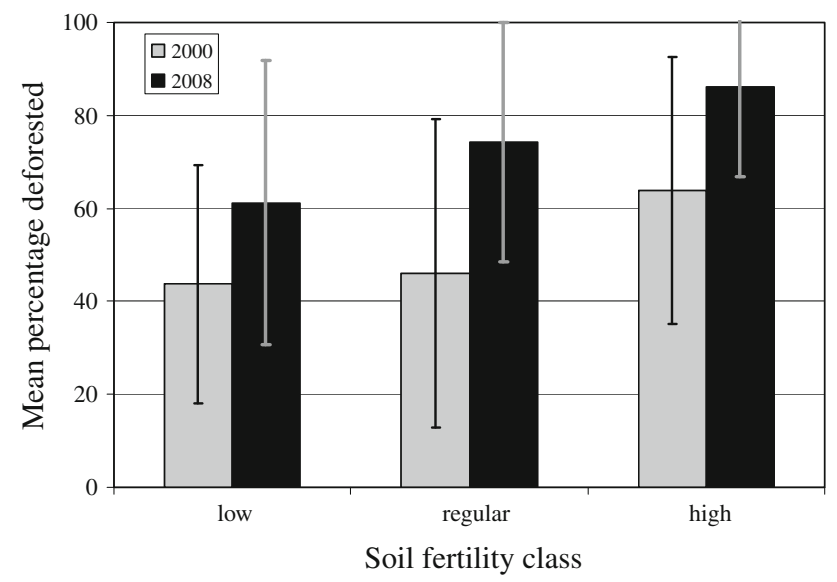

Fig. 7 Percentage deforested per property for different soil fertility classes estimated based on household level data for 2000 and 2008
ANOVA analysis between the year of establishment and the percentage deforested indicated that the deforested area of very old projects in 2000 still differed significantly from old, new and newer projects $(p<0.07)$. As a result of the high deforestation in old and new projects between 2000 and 2008, the mean percentage deforested among very old, old and new projects was statistically similar, only differing significantly from newer projects $(p<0.05)$.

The Pearson correlation results among percentage deforested in 2000 and 2008, distance to BR-364 and means of access (i.e. the nearest road type defined by the average travel speed following Table 2) showed that the year of establishment of agrarian projects is highly correlated to the distance to BR-364 and the means of access $(p<0.01)$. Older projects are usually closer to BR-364 and have consequently the best access type. In addition, distance to BR364 and means of access were also significantly correlated $(p<0.01)$ to the percentage deforested per property in 2000. However, in 2008, these correlations drop and only distance to BR-364 remains significant $(p<0.05)$.

The regression models explaining deforested area based on the household level data are presented in Table 5. Although the importance of all variables is comparable for both years, it is observed that the year of occupation has a larger role in explaining deforestation and is more important in the 2000 model while the variables describing the access situation are more important in 2008. The models including all variables explain $40 \%$ of the variation between households $(p<0.01)$. Given the high variation in household level behavior and conditions, this can be considered a reasonable fit, indicating that we have captured a number of key determinants of deforestation patterns.

\section{Discussion}

Both types of analysis presented in this paper add insight into the determinants of deforestation processes in the region. The two types of analysis cannot be integrated in a

Table 5 Standardized coefficients of independent variables of linear regression explaining the percentage deforested per property in 2000 and 2008

\begin{tabular}{lcc}
\hline Reference year & \multicolumn{1}{l}{2000} & \multicolumn{1}{c}{2008} \\
\hline High fertility & 0.1270 & 0.1473 \\
Low fertility & -0.1109 & -0.1910 \\
Property size & -0.2251 & -0.3090 \\
Year of establishment & -0.6611 & -0.4661 \\
Means of access & -0.1112 & -0.2477 \\
Distance to BR-364 & 0.0338 & -0.1681 \\
$R^{2}$ & 0.395 & 0.334 \\
\hline
\end{tabular}


simple manner due to measurement differences. While the household level analysis measures the processes at the level of the properties of individual households, the spatial analysis measures the change for the entire territory of the region, including land not allocated to households. Therefore, the fractions deforested as calculated by the different methods are not similar and have a different meaning. At the same time, a comparison of the findings of the different methods of analysis helps to provide insight into the processes of land change in the region.

\section{The role of land use planning}

The spatial analysis clearly shows higher deforestation inside agrarian projects. Deforestation rates inside the projects in the study area were estimated at $2.3 \%$ per year between 2000 and 2008, which is two times the deforestation rate of Rondônia as a whole during the same period (INPE 2009). Even though less deforested, areas outside the agrarian projects presented comparable deforestation rates to agrarian projects between 2000 and 2008. These results add empirical input to the discussion on the role of land use planning and colonization policies in deforestation in Rondônia (Pacheco 2009; Rodrigues et al. 2009). As a result of the past and current spatial zoning of the study area, the contribution of small farmers is significant on the total deforested area. However, medium and big farms, more common in areas outside the agrarian projects, have contributed similarly to the average deforestation rates in the region.

With respect to the year of establishment of the agrarian projects, spatial data and household level data presented differences in the deforested area. Explanations for this difference include the limitation of the TM sensor-derived data of 6.25 ha as the minimum identified deforested area. This limitation can result in overestimated deforestation in highly fragmented areas (as result of ignoring small remnants of secondary forest) or underestimate deforestation in areas with low forest fragmentation. However, the high deforestation rates given by household level data in old projects are not well explained by such limitations. Instead, the sampling method is most likely another reason for the high deforestation rates observed. The old projects sampled are located in municipalities among the most deforested in Rondônia during the last 8 years (INPE 2009). Old agrarian projects located in the southern part of the study area were not included in the sample due to logistic problems during fieldwork. Finally, the main explanation for these dissimilarities lies in the differences in measurement. Whereas the household level data report on deforestation within the properties, the spatial data estimates also include the areas not allocated to individual properties, thus leading to a different measurement.
Remote sensing data indicate that the fractions deforested in 2000 and 2008 are larger in agrarian projects established after 2000 (newer) than in the projects established in the 1990s (new). Expert analysis and field observations have shown that most of the newer projects in Rondônia are being created in unofficial colonization areas previously occupied by big or medium landholders. This is confirmed by deforestation patterns observed in Landsat/ TM satellite images previous to 2000 inside areas currently defined as newer projects, i.e., beforehand official land demarcation. In addition, the lots in newer projects tend to be smaller, leading to faster forest depletion.

Because of the small number of samples in situ outside the agrarian projects, the estimates obtained from remote sensing for such areas are certainly more reliable. Due to the intrinsic limitation of obtaining a representative sample outside the agrarian projects and the poor accessibility to some newer projects, the deforestation estimates based on the household level data may be biased, leading to less reliable results when compared to the spatial analysis.

\section{Patterns of forest clearing size}

Different categories of landholders are related to the size of forest clearing as identified by spatial data. While inside agrarian projects, the forest clearings were smaller, characteristic of small landholders, outside the projects, larger forest clearings are likely connected to big landholders. The results in very old and old agrarian projects indicate that these projects have similar deforestation dynamics. These two groups of projects can be considered consolidated settlements. In these areas, the amount of forest remnants was estimated around $18 \%$, which can be connected to a high frequency of forest clearings smaller than 10 ha. Both at the scale of individual plots and the agrarian projects as a whole, the deforestation exceeds $50 \%$ of the total area. Deforestation up to $50 \%$ of the total property size is not allowed by the Brazilian Forestry Code. The exceeding of $50 \%$ deforestation even in recently created projects (new and newer) indicates that the objectives of the Forestry Code are no longer realistic for most of the area considered. This is not only an indication that forest is highly fragmented in areas of old frontiers, but also that forest depletion can be significant at the property level already after 10-14 years of occupation in the study area.

Even though intense forest depletion happens in old frontiers, spatial analysis showed that forest clearings between 10 and 60 ha are found in all agrarian projects. These larger forest clearings are often related to aggregation of lots. Previous studies have indicated similar processes of land concentration in old settlements in the same region at the cost of forest remnants and secondary forest 
(Alves et al. 1999; Escada 2003; Millikan 1992). Spatial analysis also showed that forest clearings between 60 and 200 ha and larger than 200 ha were important in newer agrarian projects. Based on fieldwork information and literature review, two main reasons were identified. Both the larger forest clearings taking place during the initial phase of occupation and the forest conversion into large-scale agriculture/pasture activities (as a consequence of land concentration processes) can explain the importance of large forest clearings. The first hypothesis does not apply for all newer projects, once a considerable number of them had a high fraction deforested already in 2000, reflecting previous occupation processes before INCRA's land demarcation. Thus, aggregation of lots may be an important reason for the high deforestation rates. Lot aggregation processes in some newer projects were observed in the field and also reported by INCRA in the study area.

The results found in this study confirm the findings of studies in the Ecuadorian Amazon (Messina et al. 2006; Pan et al. 2004) that spatial patterns of deforestation are often closely related to the land use history, colonization process and spatial policies including land tenure situations. At the same time, due to the different policies and context, the landscape patterns develop differently in these different regions.

\section{The influence of property size}

The analysis of the deforested area in relation to property size distribution at municipality level indicated that municipalities with a high percentage of properties smaller than 240 ha are more deforested. This reveals the significant contribution of small farmers settled by INCRA on deforestation processes in the region, also shown in the literature (Alves 2002; Brandão and Souza 2006). A similar result was found based on the analysis of household level data. Therefore, both data sources indicate that small properties play an important role in total deforestation and large properties contributed more significantly to deforested patches within 2000 and 2008. Even though in the spatial analysis at the municipality level, the risk of ecological fallacy due to scaling issues of aggregated data must be considered, the similar results of property size influence on deforestation in both data sources indicate the complementarity of the analyses.

When connected to the size of forest clearing, it was observed that $61 \%$ of the total deforestation within 20002008 was due to patches smaller than 60 ha, which are related to small farmers. Conversely, forest clearings larger than 60 ha represented $39 \%$ of the total deforestation in the same period and are mostly correlated to the larger properties. Similar results were found in previous studies in Rondônia (Alves 2002; Fearnside 1993).
Year of occupation and soil fertility

Both spatial and household level analyses draw the attention to the year of occupation, revealing that deforestation is more intense in old frontiers. Household level data indicated a temporal dependence between the year of occupation and the percentage deforested at the property level, as deforestation is higher during the first years of occupation and declines when forest remnants decrease. Besides, in a few interviews in very old and old projects, very low deforestation rates were connected to poor soil fertility and steep terrain of the remaining forest land.

The ANOVA results showed high soil fertility as an important determinant of deforestation in the study area, with similar indications noted by other authors in the same area and for the Amazon as a whole (Aguiar et al. 2007; Numata et al. 2003).

\section{Accessibility}

The analyses of accessibility measures across different zones showed that both travel time and road density are highly correlated to previous deforestation inside and outside agrarian projects. The analysis of road patterns revealed that occupation in some areas inside new and newer agrarian projects such as Buritis and Campo Novo de Rondônia have been driven first by logging activities linked to orthogonal and irregular patterns, followed by small farmers claiming land tenure. On the other hand, the increase in accessibility to forest in spontaneous colonization indicates a frontier of expansion, also observed in conservation reserves and indigenous areas. Despite of being related to different planning systems, both orthogonal and dendritic road patterns contribute similarly to forest fragmentation, while the year of establishment rather than the settlement design is a key determinant of forest clearing. At the household level, the results indicated that the means of access and distance to BR-364 determine significantly the deforested area in the properties. These results confirm the observations through remote sensing data. Furthermore, they indicate that accessibility plays an important role in the beginning of the colonization process, determining the deforestation rate. A similar conclusion was made by Mertens et al. (2002) based on observations done in Para State at a similar spatial scale.

Deforestation patterns in Rondônia are sometimes seen as a result of synergism among soil fertility, distance to markets and land availability (Roberts et al. 2002). The regression model derived in this paper (Table 5) confirms this hypothesis by listing year of occupation as the dominant determinant of deforestation patterns, while soil fertility and accessibility are important contributors to the explanation in the spatial variation of deforestation. 


\section{Conclusions}

Remote sensing and household level data indicate the similar patterns of land cover change for the study area. Even though the different data sources present some divergent results, a careful analysis accounting for the limitations of data sources can lead to complementary conclusions. Examples are that both data sources showed that small farmers contribute significantly to total deforestation in the area, as well as that well-established areas with better accessibility tend to be more deforested. However, because of its ability to provide a synoptic view of large areas, remote sensing data are more suitable to identify overall patterns and to estimate the total percentage deforested. On the other hand, some determinants of deforestation especially in recently created settlements and the influence of processes like lot aggregation can only be revealed by analysis of household level data.

The complementary use of both household level and remote sensing data has been proved useful in previous studies (Fox et al. 2002; Overmars and Verburg 2005; Rindfuss et al. 2003, 2008). Rindfuss et al. (2003) and Pan et al. (2004) have used methods that actually integrate remote sensing data and household surveys by delineating the property areas of sampled households within the spatial data. Such a linkage allows a relatively straightforward and consistent integration of the different data types. However, this method needs intensive fieldwork in delineating the property boundaries and is, therefore, only feasible for small regions or in cases with adequate cadastral information. Overmars and Verburg (2005) have, similar to this study, compared the results of analysis at household level with an analysis of spatial data and interpreted the results to achieve a complementary understanding of the region.

This study has also indicated that in relatively large regions insights into land cover change and regional determinants of deforestation processes can be improved when the analysis is based on both spatial data (based on remote sensing images) and household level data.

The analysis shows a significant contribution of both small scale and medium to large scale landholders to deforestation. It also shows the year of establishment together with accessibility, soil fertility and forest remnants as important determinants of patterns and allocation of deforestation. It should be noted that a large portion (38\%) of the occupied area is allocated to agrarian projects. Thus, the conclusions could be only extended to specific areas in the Brazilian Amazon. The analysis also reinforces an ongoing discussion of the urgent need of public policies to tackle the different land use trajectories of small and big landholders in current issues as biodiversity maintenance, forest recovery, carbon credits and biofuel initiatives. Such policies must consider not only biophysical and accessibility constraints, but also the land use history that includes land tenure issues.

Acknowledgments This research was funded by the Dutch National Science Foundation (NWO-WOTRO) project "Vulnerability and resilience of the Brazilian Amazon forest and human environment to changes in land use and climate". The authors would like to thank the Secretaria de Desenvolvimento Ambiental de Rondônia (SEDAM) and the Institute for Colonization and Agrarian Reform (INCRA) for providing agrarian projects data and for fieldwork support. The two anonymous reviewers are acknowledged for their constructive comments in a previous version on this paper.

Open Access This article is distributed under the terms of the Creative Commons Attribution Noncommercial License which permits any noncommercial use, distribution, and reproduction in any medium, provided the original author(s) and source are credited.

\section{References}

Aguiar APD, Câmara G, Escada MIS (2007) Spatial statistical analysis of land-use determinants in the Brazilian Amazonia: exploring intra-regional heterogeneity. Ecol Model 209:169-188

Alves DS (2002) Space-time dynamics of deforestation in Brazilian Amazonia. Int J Remote Sens 23:2903-2908

Alves DS, Pereira JLG, Sousa CLD, Soares JV, Yamaguchi F (1999) Characterizing landscape changes in central Rondonia using Landsat TM imagery. Int J Remote Sens 20:2877-2882

Alves DS, Escada MIS, Pereira JLG, Linhares CD (2003) Land use intensification and abandonment in Rondonia, Brazilian Amazonia. Int J Remote Sens 24:899-903

Arima EY, Walker RT, Perz SG, Caldas M (2005) Loggers and forest fragmentation: behavioral models of road building in the Amazon basin. Ann Assoc Am Geogr 95:525-541

Batistella M (2001) Landscape change and land-use/land-cover dynamics in Rondônia, Brazilian Amazon. Indiana University, Bloomington

Becker B (1997) Amazônia. Ática, São Paulo

Becker B (2004) Amazônia: Geopolítica na virada do III milênio. Garamond, Rio de Janeiro

Brandão AO, Souza CM (2005) Avaliação de imagens Landsat para identificação e extração de estradas madeireiras. In: INPE (ed) XII Brazilian remote sensing simposium. INPE, Goiânia, pp 3503-3509

Brandão AO, Souza C (2006) Deforestation in land reform settlements in the Amazon In: IMAZON (ed) State of the Amazon. IMAZON, Belém, p 4

Brandão AO, Souza CM, Ribeiro JGF, Sales MHR (2007) Deforestation and unofficial roads in the Amazon. In: XIII Brazilian Simposium of Remote Sensing. Florianópolis, Brazil, pp 2357 2364

Browder JO, Pedlowski MA, Summers PM (2004) Land use patterns in the Brazilian Amazon: comparative farm-level evidence from Rondonia. Hum Ecol 32:197-224

Browder JO, Pedlowski MA, Walker R, Wynne RH, Summers PM, Abad A, Becerra-Cordoba N, Mil-Homens J (2008) Revisiting theories of frontier expansion in the Brazilian Amazon: a survey of the colonist farming population in Rondonia's post-frontier, 1992-2002. World Dev 36:1469-1492

Cardille JA, Foley JA (2003) Agricultural land-use change in Brazilian Amazonia between 1980 and 1995: evidence from 
integrated satellite and census data. Remote Sensing Environ $87: 551-562$

Coy M (1987) Rondônia: frente pioneira e o programa polonoroeste. $\mathrm{O}$ processo de diferenciação sócioeconômica na periferia e os limites do planejamento público. Tubinguen Geographische Studien 95:253-270

Dale VH, Oneill RV, Southworth F, Pedlowski M (1994) Modeling effects of land management in the Brazilian settlement of Rondonia. Conserv Biol 8:196-206

Escada MIS (2003) Evolução de padrões da terra na região CentroNorte de Rondônia. National Institute for Space Research (INPE), São José dos Campos

Faminow MD (1997) Spatial economics of local demand for cattle products in Amazon development. Agric Ecosyst Environ 62:1-11

Fearnside PM (1986) Settlement in Rondonia and the token role of science and technology in Brazil Amazonian developmentplanning. Interciencia 11:229-236

Fearnside PM (1993) Deforestation in Brazilian Amazonia: The effect of population and land tenure. Ambio 22:537-545

Fearnside PM (1997) Limiting factors for development of agriculture and ranching in Brazilian Amazonia. Rev Bras Biol 57:531-549

Fearnside PM (2005) Deforestation in Brazilian Amazonia: history, rates, and consequences. Conserv Biol 19:680-688

Fearnside PM (2008) The roles and movements of actors in the deforestation of Brazilian Amazonia. Ecol Soc 13(1):23. http://www.ecologyandsociety.org/vol13/iss11/art23/

Fox J, Rindfuss RR, Walsh SJ, Mishra V (2002) People and the environment; approaches for linking household and community surveys to remote sensing and GIS. Kluwer, Boston

Fujisaka S, Bell W, Thomas N, Hurtado L, Crawford E (1996) Slashand-burn agriculture, conversion to pasture, and deforestation in two Brazilian Amazon colonies. Agric Ecosyst Environ 59:115130

IBAMA (2005) Online database In: Instituto Brasileiro do Meio Ambiente e dos Recursos Naturais Renováveis. MMA (Ministério do Meio Ambiente), Brasília

IBGE (1970) Censo agropecuário 1970

IBGE (1981) Crescimento e distribuição da população brasileira: 1940-1980. Instituto Brasileiro de Geografia e Estatística (IBGE), Rio de Janeiro

IBGE (1996) Censo agropecuário 1996

IBGE (2000) Censo demográfico 2000

IBGE (2006) Censo agropecuário 2006

IBGE (2007) Censo demográfico 2007

IBGE (2008) Banco de dados agregados-Pesquisas Municipais Pecuária, Agrícola e Industrial

INCRA (2007) Statistical data per category of rural property

INCRA (2008) Plans of agrarian projects in the north of Rondônia State. INCRA, Ariquemes

INPE (2009) PRODES-monitoring the Brazilian Amazonian forest by satellite images

Laurance WF, Albernaz AKM, Schroth G, Fearnside PM, Bergen S, Venticinque EM, Da Costa C (2002) Predictors of deforestation in the Brazilian Amazon. J Biogeogr 29:737-748

Laurance WF, Albernaz AKM, Fearnside PM, Vasconcelos HL, Ferreira LV (2004) Deforestation in Amazonia. Science 304:1109

Lorena RB (2008) Linking spatial patterns of land-use to agents of deforestation in the Brazilian Amazon. Université Catholique de Louvain, Louvain-la-Neuve

Lorena RB, Lambin EF (2009) The spatial dynamics of deforestation and agent use in the Amazon. Appl Geogr 29:171-181

Machado LO (1989) Mytos y realidade de la Amazônia Brasileña en el contexto geopolítico mundial (1540-1912). Ph.D., Barcelona University, Barcelona, Spain
Machado L (ed) (1998) A fronteira agrícola na Amazônia. Cia das Letras, São Paulo

Mello AJH, Alves DS (2005) Padrões de desflorestamento no regime fundiário de fronteira da Amazônia brasileira In: XII Simpósio Brasileiro de Sensoriamento Remoto. Goiânia, Brazil, pp 3053 3060

Mertens B, Poccard-Chapuis R, Piketty MG, Lacques AE, Venturieri A (2002) Crossing spatial analyses and livestock economics to understand deforestation processes in the Brazilian Amazon: the case of Sao Felix do Xingu in South Para. Agric Econ 27:269294

Messina JP, Walsh SJ, Mena CF, Delamater PL (2006) Land tenure and deforestation patterns in the Ecuadorian Amazon: conflicts in land conservation in frontier settings. Appl Geogr 26:113-128

Millikan BH (1992) Tropical deforestation, land degradation, and society-lessons from Rondonia, Brazil. Lat Am Perspect 19:45-72

Moran EF, Brondizio ES, Tucker JM, da Silva-Forsberg MC, McCracken S, Falesi I (2000) Effects of soil fertility and landuse on forest succession in Amazonia. For Ecol Manag 139:93108

Numata I, Soares JV, Roberts DA, Leonidas FC, Chadwick OA, Batista GT (2003) Relationships among soil fertility dynamics and remotely sensed measures across pasture chronosequences in Rondonia, Brazil. Remote Sensing Environ 87:446-455

Overmars KP, Verburg PH (2005) Analysis of land use drivers at the watershed and household level: linking two paradigms at the Philippine forest fringe. Int J Geogr Inf Sci 19:125-152

Pacheco P (2009) Agrarian reform in the Brazilian Amazon: its implications for land distribution and deforestation. World Dev 37:1337-1347

Pan WKY, Walsh SJ, Bilsborrow RE, Frizzelle BG, Erlien CM, Baquero F (2004) Farm-level models of spatial patterns of land use and land cover dynamics in the Ecuadorian Amazon. Agric Ecosyst Environ 101:117-134

Pedlowski MA, Dale VH, Matricardi EAT, da Silva EP (1997) Patterns and impacts of deforestation in Rondonia, Brazil. Landsc Urban Plan 38:149-157

RADAMBRASIL (1978) Folha SC.20-Porto Velho In: Levantamento de Recursos Naturais. IBGE, Rio de Janeiro

Rindfuss RR, Walsh SJ, Mishra V, Fox J, Dolcemascolo GP (2003) Linking household and remotely sensed data, methodological and practical problems. In: Fox J, Rindfuss RR, Walsh SJ, Mishra V (eds) People and the environment. Approaches for linking houeshold and community surveys to remote sensing and GIS edn. Kluwer, Boston, pp 1-31

Rindfuss RR, Entwisle B, Walsh SJ, An L, Badenoch N, Brown DG, Deadman P, Evans TP, Fox J, Geoghegan J, Gutmann M, Kelly M, Linderman M, Liu J, Malanson GP, Mena CF, Messina JP, Moran EF, Parker DC, Parton W, Prasartkul P, Robinson DT, Sawangdee Y, Vanwey LK, Verburg PH (2008) Land use change: complexity and comparisons. J Land Use Sci $3: 1-10$

Roberts DA, Numata I, Holmes K, Batista G, Krug T, Monteiro A, Powell B, Chadwick OA (2002) Large area mapping of landcover change in Rondonia using multitemporal spectral mixture analysis and decision tree classifiers. J Geophys Res Atmos 107:8073-8093

Rodrigues ASL, Ewers RM, Parry L, Souza C, Verissimo A, Balmford A (2009) Boom-and-bust development patterns across the amazon deforestation frontier. Science 324:1435-1437

Rondônia (2000) Zoneamento socioeconômico-ecológico. In: PLANAFORO report. SEDAM, Governo de Rondônia, Porto Velho, p 18

Rondônia (2004) Boletim climatológico de Rondônia ano 2004. SEDAM, Governo de Rondônia, Porto Velho 
Soares-Filho B, Assuncao RM, Pantuzzo AE (2001) Modeling the spatial transition probabilities of landscape dynamics in an amazonian colonization frontier. Bioscience 51:1059-1067

Soares-Filho B, Nepstad DC, Curran LM, Cerqueira GC, Garcia RA, Ramos CA, Voll E, McDonald A, Lefebvre P, Schlesinger P (2006) Modelling conservation in the Amazon basin. Nature 440:520-523

Soler LS, Escada MIS, Verburg PH (2009) Quantifying deforestation and secondary forest determinants for different spatial extents in an Amazonian colonization frontier (Rondonia). Appl Geogr 29:182-193
Sunderlin WD, Pokam J (2002) Economic crisis and forest cover change in Cameroon: the roles of migration, crop diversification, and gender division of labor. Econ Dev Cult Change 50:581-606

Verburg PH, Overmars KP, Witte N (2004) Accessibility and landuse patterns at the forest fringe in the northeastern part of the Philippines. Geogr J 170:238-255

Walker R, Moran EF, Anselin L (2000) Deforestation and cattle ranching in the Brazilian Amazon: external capital and household processes. World Dev 28:683-699 